\title{
Examining the Impact of Burnout Syndrome and Demographics on Impulsive Buying Behavior (IBB) in Working Places
}

\author{
Tolga Torun ${ }^{1, *}$, Isa Ipcioglu ${ }^{2}$ \\ ${ }^{1}$ Department of Management Information Systems, Faculty of Economics and Business Management, Bilecik S.E. University, Turkey \\ ${ }^{2}$ Department of Business Administration, Faculty of Economics and Business Management, Bilecik S.E. University, Turkey
}

Copyright (C) 2015 by authors, all rights reserved. Authors agree that this article remains permanently open access under the terms of the Creative Commons Attribution License 4.0 International License

\begin{abstract}
This paper examines the relationship of burnout syndrome, demographics and impulsive buying behavior among public sector employees by measuring burnout syndrome and impulsive buying behavior via using the relations of components of burnout syndrome suggested by Maslack and Jackson and impulsive buying behavior suggested by Rook and Fisher. The present study utilized a correlational, quantitative design to investigate hypotheses burnout syndrome and impulsive buying behavior components and the relationship between the given components in a sample of public sector workers. The questionnaire was adopted (a 1 to 5 rating Likert scale), used and completed by 112 workers out of 130 . The hypotheses were tested by regression analyze in order to analyze the predicted relationships between the given components and to check the significance of the routes of components suggested. The significant relationships between the components have noted. However, only one of the components of burnout syndrome has found significantly related with impulsive buying behavior.
\end{abstract}

Keywords Burnout Syndrome, Regression, Impulsive Buying Behavior, Public Sector

\section{Introduction}

Consumer decision-making style can be defined "as a mental orientation characterizing a consumer's approach to making choices" [32]. Consumer decision-making contains logical, emotional and behavioral processes [16]. Despite these 3 main effects, consumer decision-making process includes too many ingredients. Sproles and Kendall built up a scale on IBB and that scale was an earlier version of IBB. They took 40 items and called it consumer style inventory and finally they clustered consumer decision-making process in 8 sub-factors via factor analysis. These are:

1. perfectionism or high-quality consciousness;

2. brand consciousness;
3. novelty-fashion consciousness;

4. recreational, hedonistic shopping consciousness;

5. price and "value for money" shopping consciousness;

6. impulsiveness;

7. confusion over choice of brands, stores and consumer information; and

8. habitual, brand loyal orientation towards consumption.

Impulsiveness or impulsive buying behavior (IBB) is a ubiquitous and unique aspect of consumers' lifestyle [24] and a complex process that derive from the desire to satisfy multiple needs. In the earlier of 80's there are few studies that try to make a definition on impulsive buying behavior. Unfortunately, they were only focus on a classify rather than understanding the nature of it [9].The first study on IBB was based on retail stores [5] and it was point out some product categories are more sold on special days such as gas holidays on impulsive buying and applied on 154 retail stores. Results have showed that holidays are more profitable that other days and in holidays people have more impulsive buying behaviors. Stern [33] defined impulsive buying behavior by classifying as planned, unplanned, and impulse and he exhibited the product-oriented structure of impulsive buying. As seen as in the prior definitions of IBB was product oriented and it ignored the consumer motivation and it says the IBB is a speed buying process without thinking. Kollat and Willett [14] were first researchers who conducted to effect of consumers' characteristics and demographics on impulsive buying behavior. After 80 's researchers agreed on IBB involves hedonic or effective components [37]; [4]; [26]; [25]; [29]. Thus, they have started to account consumer motivations on IBB. Weinberg \& Gottwald [37] stressed on impulsive buying behavior's connection with emotions such as amusement, enthusiasm, joy and delight. Rock and Hoch [28] argued that impulsive consumers tend to enjoy purchasing more and the impulsive is result of consumer's sensation and perception driven by the environmental stimulus. Iyer [13] described impulsive buying behavior as a special case of unplanned buying process. Abratt and Goodey [1] pointed out that in-store stimuli such as POP posters can increase impulsive buying behavior. Piron [25] 
defined pimpulsive buying based on four criteria: unplanned, decided on the spot, stem from reaction to a stimulus and involve either a cognitive reaction, or an emotional reaction, or both. Hoch and Loewenstein [11] suggested that buying triggers more buying by loss of self-control. Rook [26] describes IBB as "Impulse buying occurs when a consumer experiences a sudden, often powerful and persistent urge to buy something immediately. The impulse to buy is hedonically complex and may stimulate emotional conflict. Also, impulse buying is prone to occur with diminished regard for its consequences". Rook and Fisher [29] conceptualized IBB as a consumer trait and defined buying impulsiveness as buying "spontaneously, unreflectively, immediately, and kinetically." Verplankan and Herabadi [36] defined, impulse buying as unplanned a sudden purchase, which is initiated on the spot. In all definitions, it's described as more arousing, less deliberate, and more on irresistible purchase behavior compared to the planned purchasing behavior [19].

Impulsive buying behavior has great effect on consumer's emotions such as amusement, enthusiasm, joy and delight [37]. Considering the relationship with emotions, IBB is a reflection of materialism, sensation seeking and recreational aspects of shopping [26]. IBB is an unplanned purchase that is characterized by relatively rapid decision making and a subjective bias in favour of immediate possessions. Customer's mood states may result in IBB [27]. In this buying process both negative and positive feelings state of consumers buying motivators [39]. Comparing negative feelings to positive feelings, negative moods are driving force than positive moods. IBB could be a result of negative state of mind [36]. Finally, IBB has hedonic and fashion aspects. Hedonic consumption has an indirect effect on fashion-oriented IBB. Fashion oriented people are seeking for pleasure and enjoyment [23].

Most of the studies have approached to impulsive buying behavior as a disorder or an emotional deficiency. However a few of studies have conducted to its nature that may convert negative moods to positive moods. Such IBB can give people happiness, joyful and life satisfaction. In this respect, it can be a key factor to get rid of daily life's conflict, exhaustion and bad feelings. Especially in strenuous and unpleasant working places, people can be motivated with this buying behavior. Thus, it's good to examine the relationship with burnout syndrome, demographics and IBB. In this manner, managers, marketers or even consumers can put forward a salience cure to working life's difficulties.

\subsection{Demographics and Burnout Syndrome and Their Relationships with Impulsive Buying Behavior}

There are some researches that show the relationship between demographics and impulsive buying behavior (IBB). IBB tends to increase between the ages of 18-39. And also researches show that it also decreases after 39 [2]; [38]. In another study, gender and income was debated. In this study, impulsive buying behavior was found related with gender and income. Also there are significant differences between marital status across gender differentiation [6]. In addition to, there is a connection with consumers' demographic and lifestyle characteristics and their impulsive buying susceptibility [14].

Moods also can influence impulsive buying behavior. Marketers believe that impulsive buying behavior stimulating person's pleasure feeling and IBB make people more excited. However most of the researches are based on positive moods not on negative moods [26]. Negative moods intensely affect self-control and it will increase buying behavior [10]. Consumers with negative mood hope to cure their unpleasant mood via buying process [20]. In this respect, burnout syndrome is a negative mood state in working places.

Burnout syndrome is caused by organizational factors that job stress, behavioral and physical problems. Burnout is different from other kind of organizational stress sources because of its nature that employees have to establish an intense and frequent relationship with others [34]. In a broad sense, burnout is a subjectively experienced and caused by long-term and emotionally demanding working places welded feeling of disappointment, despair, hopelessness, negative self-concept and negative attitudes towards work place, other employees and working life [7].

Burnout in working places has been researched since 1970 and especially, burnout has been under debate with stress concept. In 1974, Freudenberger used the burnout concept and it was took its place in organizational literaute. At that time, burnout was growing workload, lack of team spirit, unnecessary position change and reflections to long time working stress [8]. In recent time, the most common definition on burnout was done by Christina Maslach who also generated a scale. Maslack, Jackson and Leiter [19] defined the burnout as "as a syndrome of emotional exhaustion, depersonalization, and reduced personal accomplishment that can occur among individuals who work with people in some capacity". Exhaustion occurs as a result of one's emotional demands. Depersonalization refers to a cynical, negative or detached response to care recipients/patient. The reduced personal accomplishment refers to a belief that one can no longer work effectively with clients/patients/care recipients [15].

\section{Exhaustion}

1. I feel myself away from my job.

2. At the end of the day, I feel myself exhausted.

3. I feel myself exhausted when I get up a new morning.

4. It's really get me nervous when I thinking myself working with others all the day.

5. This job is consuming me.

6. This job let me down.

7. I feel myself working a lot.

8. It's really stressful that directly working people.

9. I feel myself so desperately.

\section{Depersonalization}

1. The people who I'm working for treat me like I'm not here.

2. When I'm thinking about my years in this job, I've become more callous day by day.

3. I'm not comfort about sensitive callous about the job.

4. I don't care about the people who I'm working for.

5. I feel like that people who I'm working for blame me for something. 
Table 1. Conditions of Burnout Syndrome

\begin{tabular}{|c|c|c|}
\hline Physical & Memory Problems & Psychological/Emotional \\
\hline $\begin{array}{c}\text { Exhaustion } \\
\text { Headaches } \\
\text { Imsomnia } \\
\text { Dyspnea } \\
\text { Drowsiness } \\
\text { Weight Loss } \\
\text { Often İllness } \\
\text { Digestive Systems Sick } \\
\text { Rapid Pulses } \\
\text { The Collapse Of The İmmune System }\end{array}$ & $\begin{array}{c}\text { Behavioral Symptoms } \\
\text { Irritability } \\
\text { Not Want To Work Even Hating } \\
\text { Skepticsm } \\
\text { Susceptibility, Unappreciated Feeling } \\
\text { Job Dissatisfaction, Arrive Late For Work } \\
\text { Reduce Of Self-Esteem And Self-Confidience } \\
\text { Problems With Close Friends } \\
\text { İsolation, Withdrawal And Distress } \\
\text { Submission, Guilt } \\
\text { Fracture Of Enthusiasm, Despair, Crying, Difficulties } \\
\text { On Concentration } \\
\text { Forgetfulnessi Lack Of Moving } \\
\text { Projections Of Problems } \\
\text { Be Engaged İn Self-Mental } \\
\text { Inability To Organize } \\
\text { Role Conflict, Confusion About Roles And Rules } \\
\text { Undoubt To People } \\
\text { Loss Of Interest For The Company } \\
\text { Postpone Something } \\
\text { Failure Feeling } \\
\text { Resistance in Working }\end{array}$ & $\begin{array}{c}\text { Family Problems } \\
\text { Sleep Disorder } \\
\text { Depression } \\
\text { Psychological Disorders } \\
\text { Disappointment } \\
\text { Hopelessness } \\
\text { Estrangement } \\
\text { Anxiety } \\
\text { Decrease İn Self-Esteem } \\
\text { Susceptibility } \\
\text { Apathy } \\
\text { Concern }\end{array}$ \\
\hline
\end{tabular}

\section{Reduced Personal Accomplishment}

1. I can feel what people who I'm working for think about me.

2. I effectually solve the peoples who I'm working for problems.

3. I effect people's life in a good way.

4. I feel myself energetic.

5. I can provide a good working condition to people who I'm working for.

6. I feel myself richness when I'm working close to my boss.

7. I have completed too many valuable tasks in this job.

8. I'm really calm when I overcome the emotional problems.

Burnout syndrome has an effect on both the job's quality and individual's health. Burnout syndrome can show itself as behavioral and psychological disorders [22]. Although there are too many indications about burnout, there are some conditions that trigger the burnout syndrome that are shown in Table 1 [17].

Impulsive buying behavior is a tend to buy more on impulse. Consumers buy products for a variety of non-economic reasons, such as fun, fantasy, social or emotional gratification, situational factors and social norms [32], [3]. Thus, IBB is neither an illogical process nor a risky behavior [3]. Consumers sometimes make IBB due to their negatively mood and feel better. Hence, IBB is a kind of motivation factor for consumers [31]. Impulse buying behavior relates to the high emotional activation, low cognitive control and spontaneous behavior in the proximity of an appealing object of attraction [30]. Due to the burnout syndrome, especially employees are seeking for motivation factors to break away from difficulties and bad mood situations and would expose to impulsive buying behaviors.

In this paper effects of demographics and burnout syndrome components which are exhaustion, depersonalization and reduced personal accomplishment on impulsive buying behavior will be investigated.

\section{Method}

This section describes the data analyzed and reveals some empirical facts about burnout syndrome and impulsive buying behavior relations. The aim of this study is to explore the phenomenon of relationships of between burnout syndrome components and impulsive buying behavior among employees in public sector via using the relations of components of burnout suggested by Maslack and Jackson [18] and impulsive buying behavior by Rook and Fisher [29]. The present study utilized a correlational, quantitative design to investigate hypotheses about the relationship between the given burnout syndrome components and impulsive buying behavior. A survey method was used to collect data and applied in a sample of public revenue office employees in Bilecik province of Turkey. The questionnaire administered 10 minutes to complete and the survey was applied via face to face communication. After deleting missing values, 112 usable survey sheets were issued to analyze.

The questionnaire included questions about demographics, impulsive buying behavior and burnout syndrome. Respondents were asked about their opinions on a five-point likert-like scale where 1 means strongly disagree and 5 means strongly agree. As mentioned in the above section burnout syndrome has 3 dimensions and impulsive buying behavior has only one dimension to put into test model. In this model also demographics were included to investigate into relationships among IBB, burnout syndrome (see Figure 1). And hypotheses were created to test. The study conducts to IBB and it has 9 statements which were adopted from Rook and Fisher's [29] study. And also it conducts to burnout syndrome and it has 3 dimensions: exhaustion that has 9; depersonalization that has 5; reduced personal accomplishment that has 8 statements which are adopted from Maslack and Jackson's [18] study. 


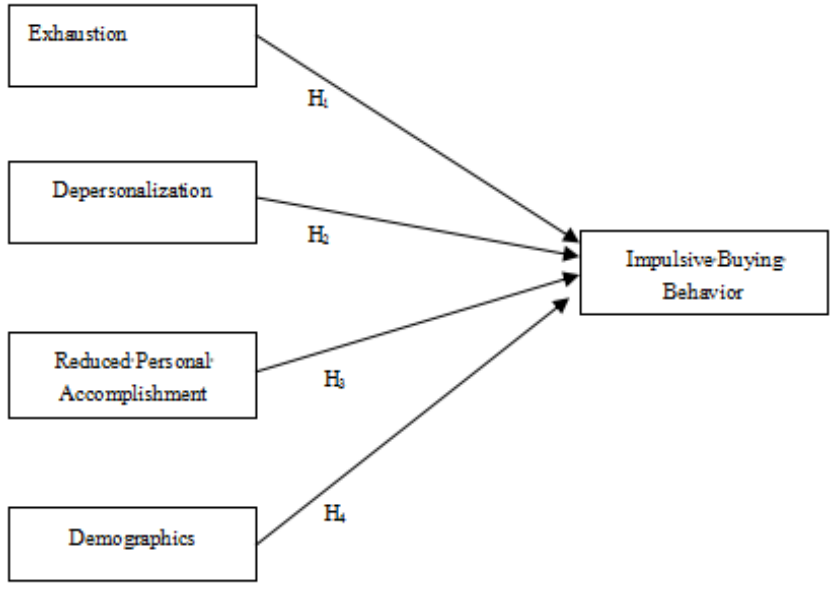

Figure 1. Research Model

For testing the following hypothesis we consulted to regression analyses in SPSS 13 and we tested the given model measurement model especially to check out the existence of study's latent variables and secondly whether these latent variables manifest themselves in the study's observed variables [12]. Therefore these hypothesizes are developed;

$\mathrm{H}_{1}$ : Exhaustion has effect on impulsive buying behavior.

H2: Depersonalization has effect on impulsive buying behavior.

H3: Reduced personal accomplishment has effect on impulsive buying behavior.

H4: Demographics have effect on impulsive buying behavior.

H4a: Marital status has effect on impulsive buying behavior.

H4b: Gender has effect on impulsive buying behavior. behavior.

$\mathrm{H} 4 \mathrm{c}$ : Working groups has effect on impulsive buying

Table 2. Demografic Characters of Sample and Cronbach Alpha's for Variables

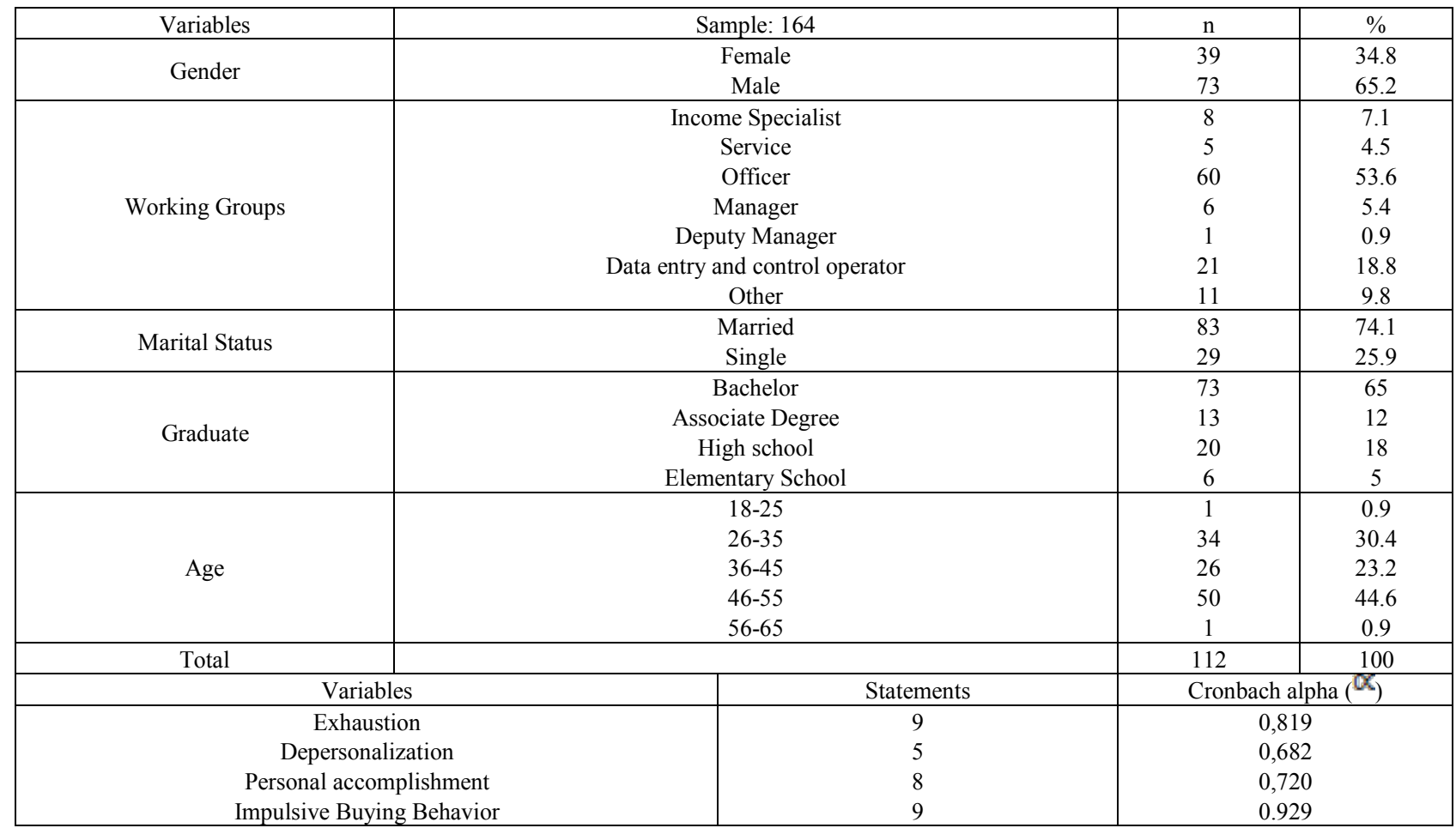

H4d: Educational level has effect on impulsive buying behavior.

H4e: Age has effect on impulsive buying behavior.

The participants in the present study were recruited among members of public revenue office for targets of burnout syndrome and impulsive buying behavior. The sample is 112 people, $39(34.8 \%)$ were female and $73(65.2 \%)$ male (see Table 1. for main characteristics). Almost half of the people in the sample are officers (53.6\%) and $18.8 \%$ are data entry and control operator. Majority of the sample have bachelor degree $(65 \%)$. The internal consistency (Cronbach's alpha) for the full survey were in between 0.682 ve 0.929 and acceptable-over 0,60 (see Table 2 for each component's alpha score).

\section{Validity and Reliability}

In order to test the validity and reliability, cronbach alpha's and exploratory factor analysis (EFA) were used.

For the reliability of scales was determined by computing KMO scores and cronbach's alphas shown in Table 2. As can be seen all scales have acceptable alpha values.

We consulted to EFA with varimax rotation, and factor loadings of $\geq 0.50$ were used as comparison and in Table 2 profiles of each factor are shown. The results show one statement of exhaustion scale was deleted and 8 statements were appointed to 1 factor. One statement of depersonalization scale was deleted and 4 statements of it were appointed to 1 factor. One statement of personal accomplishment scale was deleted and 7 statements of it were appointed to 1 factor. Finally 9 statements of impulsive buying behavior scale were loaded to 1 factor.

\section{Results}


Table 3. Factor Loading for Statements

\begin{tabular}{|c|c|}
\hline Factors & Loading \\
\hline $\begin{array}{l}\text { Exhausition } \\
\text { 1. I feel myself away from my job. } \\
\text { 2. At the end of the day, I feel myself exhausted. } \\
\text { 3. I feel myself exhausted when I get up a new morning. } \\
\text { 4. It's really get me nervous when I thinking my self-working with others all the day. } \\
\text { 5. This job is consuming me. } \\
\text { 6. This job let me down. } \\
\text { 7. I feel myself working a lot. } \\
\text { 8. It's really stressful that directly working people. } \\
\text { 9. I feel myself so desperately. }\end{array}$ & $\begin{array}{l}0.696 \\
0.677 \\
0.796 \\
0.602 \\
0.811 \\
0.593 \\
0.366 \\
0.657 \\
0.525\end{array}$ \\
\hline \multicolumn{2}{|l|}{$\%$ of Variance $=42.104 ;$ Eigenvalues $=3.789$} \\
\hline $\begin{array}{l}\text { Depersonalization } \\
\text { 1.The people who I'm working for treat me like I'm not here. } \\
\text { 2. When I'm thinking about my years in this job, I've become more callous day by day. } \\
\text { 3. I'm not comfort about sensitive callous about the job. } \\
\text { 4. I don't care about the people who I'm working for. } \\
\text { 5. I feel like that people who I'm working for blame me for something. }\end{array}$ & $\begin{array}{l}0.687 \\
0.693 \\
0.232 \\
0.777 \\
0.704\end{array}$ \\
\hline \multicolumn{2}{|l|}{$\%$ of Variance $=51,262 ;$ Eigenvalues $=2.050$} \\
\hline $\begin{array}{l}\text { Personal Accomplishment } \\
\text { 1. I can feel what people who I'm working for think about me. } \\
\text { 2. I effectually solve the people's who I'm working for problems. } \\
\text { 3. I effect people's life in a good way. } \\
\text { 4. I feel myself energetic. } \\
\text { 5. I can provide a good working condition to people who I'm working for. } \\
\text { 6. I feel myself richness when I'm working close to my boss. } \\
\text { 7. I have completed too many valuable tasks in this job. } \\
\text { 8. I'm really calm when I overcome the emotional problems. }\end{array}$ & $\begin{array}{l}0.565 \\
0.601 \\
0.581 \\
0.495 \\
0.566 \\
0535 \\
0.707 \\
0.593 \\
\end{array}$ \\
\hline \multicolumn{2}{|l|}{$\%$ of Variance $=34.023 ;$ Eigenvalues $=2.722$} \\
\hline $\begin{array}{l}\text { Impulsive Buying Behavior } \\
\text { 1. I often buy things spontaneously. } \\
\text { 2. "Just do it" describes the way I buy things. } \\
\text { 3. I often buy things without thinking. } \\
\text { 4. "I see it, I buy it" describes me. } \\
\text { 5. "Buy now, think about it later" describes me. } \\
\text { 6. Sometimes I feel like buying things on the spur of the moment. } \\
\text { 7. I buy things according to how I feel at the moment. } \\
\text { 8. I am not carefully plan most of my purchases. } \\
\text { 9. Sometimes I am a bit reckless about what I buy. }\end{array}$ & $\begin{array}{l}0.747 \\
0.762 \\
0.901 \\
0.779 \\
0.816 \\
0.858 \\
0.761 \\
0.870 \\
0.713\end{array}$ \\
\hline$\%$ of Variance $=64.485 ;$ Eigenvalues $=5.804$ & \\
\hline
\end{tabular}

Table 4. Coefficients ${ }^{\mathrm{a}}$

\begin{tabular}{|c|c|c|c|c|c|c|}
\hline \multicolumn{2}{|c|}{ Model } & \multicolumn{2}{|c|}{ Unstandardized Coefficients } & Standardized Coefficients & $\mathrm{t}$ & Sig. \\
\cline { 2 - 8 } & B & Std. Error & Beta & & 2.081 & $\mathbf{0 . 0 4 0}$ \\
\cline { 2 - 8 } & (Constant) & 1,442 & 0.0693 & & -0.424 & 0.672 \\
\cline { 2 - 8 } & Exhaustion & $-0,054$ & 0.127 & -0.047 & -0.181 & $\mathbf{0 . 0 0 2}$ \\
\cline { 2 - 8 } & Depersonalization & 0,398 & 0.125 & 0.360 & -1.077 & 0.657 \\
\hline & $\begin{array}{c}\text { Reduced Personal } \\
\text { Accomplishment }\end{array}$ & $-0,054$ & 0.121 & -0.041 & -0.160 & 0.284 \\
\hline & Working Group & -0.47 & 0.044 & -0.103 & 2.015 & $\mathbf{0 . 0 4 7}$ \\
\hline & Education Level & -0.014 & 0.085 & 0.201 & -0.353 & 0.725 \\
\hline
\end{tabular}

a. Dependent Variable: Impulsive Buying Behavior 


\section{Testing the Research Model and Hypothesis}

In the given research model, we have 1 dependent variable that is impulsive buying behavior and 4 independent variables that includes exhaustion, depersonalization, reduced personal accomplishment and demographics (gender, education level, marital status, working groups).

In this study we chose regression analysis to confirm the research model and the hypothesis. Thus, we examined the model fit and entire set of relationships that are shown in Table 3 and Table 4.

Table 3. Anova Scores of The Research Model

\begin{tabular}{|c|c|c|c|c|c|c|}
\hline \multicolumn{7}{|c|}{ ANOVAb } \\
\hline \multicolumn{2}{|c|}{ Model } & Sum of Squares & df & Mean Square & F & Sig. \\
\hline \multirow{3}{*}{1} & Regression & 10,855 & 8 & 1,357 & 2,408 &, $020 \mathrm{a}$ \\
\cline { 2 - 7 } & Residual & 58,027 & 103 & 0,563 & & \\
\cline { 2 - 8 } & Total & 68,882 & 111 & & & \\
\hline
\end{tabular}

a. Predictors: (Constant), age, gender, marital status, working group, educational level, exahustion, reduced personal accomplishment and depoersonalization.

b. Dependent Variable: ibball

In Anova test we are testing our components are fitting or not via $\mathrm{F}$ scores. Hence, in the table 3, scores show that our research model is fitting and significant at $\alpha<0.05$. In this respect, we can accept that all the components of given model have together effect on impulsive buying behavior. However, we have to look into B values to put forward strength of independent variables on dependent variable via regression analysis. In addition to, we have to examine $t$ scores to evaluate all independent variables are significant or not outside the model. Thus, we can test the hypothesis.

$\mathbf{H}_{1}$ : Exhausition has effect on impulsive buying behavior. $\mathrm{P}=0.672$ and $\alpha \leq 0.05$ condition is not provided, so

$\mathrm{H}_{1}$ is rejected.

$\mathbf{H}_{2}$ : Depersonalization has effect on impulsive buying behavior.

$\mathrm{P}=0.002$ and $\alpha \leq 0.05$ condition is provided, so $\mathrm{H}_{2}$ is accepted.

$\mathbf{H}_{3}$ : Reduced personal accomplishment has effect on impulsive buying behavior.

$\mathrm{P}=0.657$ and $\alpha \leq 0.05$ condition is not provided, so

\section{$\mathrm{H}_{3}$ is rejected.}

$\mathbf{H}_{4}$ : Demographics have effect on impulsive buying behavior.

behavior.

$\mathbf{H}_{\mathbf{4 a}}$ : Marital status has effect on impulsive buying

is accepted.

$\mathrm{P}=0.047$ and $\alpha \leq 0.05$ condition is provided, so $\mathrm{H}_{4 \mathrm{a}}$ behavior.

$\mathbf{H}_{4 \mathbf{b}}$ : Gender has effect on impulsive buying

$\mathrm{P}=0.725$ and $\alpha \leq 0.05$ condition is not provided, so

$\mathrm{H}_{4 \mathrm{c}}$ is rejected.

$\mathbf{H}_{4 \mathbf{c}}$ : Working groups has effect on impulsive buying behavior.

$\mathrm{P}=0.284$ and $\alpha \leq 0.05$ condition is not provided, so

$\mathrm{H}_{3}$ is rejected.

$\mathbf{H}_{4 \mathrm{~d}}$ : Educational level has effect on impulsive buying behavior.
$\mathrm{P}=0.873$ and $\alpha \leq 0.05$ condition is not provided, so $\mathrm{H}_{4 \mathrm{~d}}$ is rejected.

$\mathbf{H}_{4 \mathrm{e}}$ : Age has effect on impulsive buying behavior. $\mathrm{P}=0.358$ and $\alpha \leq 0.05$ condition is not provided, so

\section{$\mathrm{H}_{4 \mathrm{e}}$ is rejected.}

Due to the results research model is formulated as:

$\mathrm{IBB}=.442-0,054 \times$ Exhaustion $+0.398 \times$ Depersonalization0.054xReduced Personal Accomplisment-0.47xWorking Group-0.014xEducational Level+0.186xMarital

Status-0.080xGender

\section{Conclusions}

Burnout is a new comer notion in the Turkish literature as having ambiguity themselves, generally mistaken with daily conflicts in the workplace. Victims of burnout syndrome are generally unwilling to work and being alienated and fail to work in an organization again. Also, victims who have burnout syndrom are physically and psychologically collapsed and this failure has major personal and organizational outcomes.

Impulse buying processes are alternatives to planned decision making and consumers must use these techniques with that in mind. If impulse is a response to information overload, consumers may reduce the information processing demands by restricting their search either to a few products or to several features of a larger number of products. Thus, consumers buy products for a variety of non-economic reasons, such as fun, fantasy, social or emotional gratification, situational factors and social norms (Sproles and Kendall; 1986; Chen, 2008). Due to exhausting working life, people who have burnout syndrome are seeking for motivation factors to break away from difficulties and bad mood situations and would expose to impulsive buying behaviors.

In this study Maslack and Jackson's (1981) burnout scale and impulsive buying behavior scale used to examine their relationships. First of all socio-demographic characteristics were examined as finding that; the respondents occupational status were officer, data entry and controlling operator, income specialist and manager mainly. A large majority of the respondents were graduated as bacholar degree that here it is important to mention that they are at well-educated level. Majority of people in this sample are male.

Hypothesized items (factors of burnout syndrome) and demographics are examined and resulted that depersonalization and marital status have effect on impulsive buying behavior. Considering the results; when depersonalization starts, an employee can easily lost his/her self-awareness and it is clear that he/she may try to find out a solution to this situation. And result shows that an answer for this problem is impulsive buying behavior that related with unplanned purchase. Those, impulsive buying behavior can be a key factor to solve depersonalization disorder. Burnout syndrome is serious problem that needed to take critical precautions as it carries occupational health and safety risk especially in the public sector. For this reason, IBB must be under debate as a cure of this disorder and it should be used in a controlled way especially in exhausting jobs. 
Moreover marital status has to be considered as a factor of increasing impulsive buying behavior separately. Marketers must analysis the working places carefully and they need to make a target group through marital status. However, marital status is not enough to define for target group. Because demographics have negative and positive effect on together which are shown in results. Due to the results, gender, educational level and working groups are effecting the impulsive buying behavior negatively but small. In this respect marketers have to consider distribution of demographics.

On the other hand, for practitioners it's very important to take their places in markets where unsatisfied and depersonalization consumers are available due to capture their unplanned buying behavior to promote their moods. Hence, consumers should be more aware of retailers' efforts to manipulate their moods to influence their unplanned buying decisions. Those, retailers have to investigate the exhausting working places and try to come closer to customers via marketing efforts. In this respect, companies have to analyze working groups and focus on specific needs to serve consumers buying behaviors. Moreover, they can increase enablers by only shopping for supporting impulsive buying behavior to consumers whenever they need. However, there is a question mark on which products are buying unplanned and which are planned has to be examined. On account of this, it is a future research suggestion to put forth a solution.

When we look at the rejected hypothesis, we have found no relationship between personal accomplishment, exhaustion, gender, working groups and educational level outside the model; separately on IBB. However, size of the sample is relatively small and for that reason these hypothesis should be tested in further studies in the future with wide and different sample. In addition to small sample size, we have a generalization problem and results are only valid for the discussed sample.

\section{REFERENCES}

[1] ABRATT, R. \& GOODEY, S.D. (1990). Unplanned Buying And In-Store Stimuli In Supermarkets. Managerial and Decision Economics, 11(2), 111-121. DOI: 10.1002/mde.4090110204.

[2] BELlEnger, Danny, N., ROBERTSON, Dan H. \& HIRSHMAN, Elizabeth C.(1978). Impulsive Buying Varies By Product. Journal of Advertising Research, 18(December), $15-18$.

[3] CHEN, T. (2008). Online Impulse Buying and Product Involvement. Communications of the IBIMA, 5, 74-81.

[4] COBB, C.J. \& HOYER, W.D. (1986). Planned Versus Impulse Purchase Behavior. Journal of Retailing, 62(4), 384-409.

[5] CLOVER, V. T. (1950). Relative Importance of Impulse-Buying in Retail Stores. American Marketing Association, 15 (1), 66-70. DOI: 10.2307/1247083.

[6] DITTMAR, H. \& DRURY, J. (2000). Self-image- is it in the bag? A qualitative comparison between 'ordinary' and 'excessive" consumers. Journal of Economic Psychology, 21, 109-142.

[7] DEMIRTAŞ, H \& GÜNEŞ, H. (2002). EğitimYönetimi ve Denetimi Sözlüğü, Istanbul:Anı.

[8] GÜVEN, S. (2013). Determining of the Relationship between the Humor Styles and Burnout Levels of the Nurses Working in Surgical Clinics. Institute of Health Sciences, Program of Nursing for Surgical Diseases, Unpublished M.A. Thesis, Ankara: Başkent Üniversitesi.

[9] HAUSMAN, A. (2000). A Multi-Method Investigation Of Consumer Motivations In Impulse Buying Behavior. Journal Of Consumer Marketing, 17(5), 403-419. Doi: http://dx.doi.org/10.1108/07363760010341045.

[10] HERMAN, C., Peter \& POLIVY. J. (2004). The Self Regulation Of Eating: Theoretical And Practical Problems in Handbook of Self Regulation: Research Theory and Application ed., Roy F. Baumeis erm and Kathleen D. Vohs, New york Guil Ford Press, 429-508.

[11] HOCH, S.J. \& LOEWENSTEIN, G.F. (1990). Time-inconsistent Preferences and Consumer Self-Control. Journal of Consumer Research, 17, 492-507. DOI: http://dx.doi.org/10.1086/208573.

[12] HUCK, S. (2012). Reading Statistics and Research. 6th.Edition, Boston: Pearson Education Inc.

[13] IYER, E.S. (1989). Unplanned Purchasing: Knowledge Of Shopping Environment And Time Pressure. Journal of Retailing, 65(1), 40-57.

[14] KOLLAT, D. T. \& Willett, R.P. (1967). Consumer Impulse Purchasing Behavior. Journal of Marketing Research, 4(February), 21-31.

[15] KORUNKA, C. \& ZDREHUS, C. (2014). Source: http://www.burnoutintervention.eu/fileadmin/user_upload/B OIT_theoretical_abstract_2705.pdf. 29.12.2014.

[16] KOTLER,P. (2003), Marketing Management, Eleventh Edition, New Jersey: Person Education Inc.

[17] KOYUNCU, M. (2001). Üniversite Öğretim Elemanlarında Tükenme Duygusu ve Organizasyondan Ayrılma İsteğine Etkisi. Ulusal Yönetim ve Organizasyon Kongresi Bildirisi, 349-360.

[18] MASLACK, C., \& JACKSON, S.E. (1981). The Measurement of Experienced Burnout. Journal of Occupational Behaviour, 2, 99-113.

[19] MASLACH, C., JACKSON, S.E., \& LEITER, M.P. (1996). Maslach Burnout Inventory Manual (3rd edn.). Palo Alto, CA: Consulting Psychologists Press.

[20] MICK, D. G. \& Michelle DEMOSS, M. (1990). Self-Gifts: Phenomenological Insights from Four Contexts. Journal of Consumer Research, 17(3), 322-332.

[21] MUNUSAMY, J., LAU, B., \& SHANKAR, C. (2010). Impulse Buying Behavior in Shopping Malls: A Malaysian Perspective. Lambert Academic Publishing.

[22] ORUÇ, S.( 2007). Examining The Burnout Levels of Teachers Employed in The Special Education Schools with Some Variables /The Sample of Adana). Department of Primary School, Unpublished MA Thesis, Adana: Çukurova Üniversitesi.

[23] PARK, E. J., KIM, E. Y., \& FORNEY, J. C. (2006). A structural model of fashion-oriented impulse buying behavior. Journal of Fashion Marketing and Management, 10(4), 
433-446. http://dx.doi.org/10.1108/13612020610701965.

[24] PARBOTEEAH, D. V. (2005). A Model of Online Impulse Buying: An Empirical Study. Department of Information Systems, Unpublished Doctoral Dissertation, Washington State University.

[25] PIRON, F. (1991). Defining Impulse Purchasing. Advances in Consumer Research, 18,509-513.

[26] ROOK, D.W. (1987). The Buying Impulse. Journal of Consumer Research, 14, 189-199. Doi: DOI: $10.1086 / 209105$.

[27] ROOK, D. W., \& GARDNER, M. P. (1993). In the mood: impulse buying's affective antecedents. Research in consumer behavior, 6(7), 1-28.

[28] ROOK, D. W.\& HOCH, S. J. (1985). Consuming Impulses. Advances in Consumer Research, 12(1), 23-27.

[29] ROOK, D.W. \& FISHER, R.J. (1995). Trait And Normative Aspects Of Impulsive Buying Behavior. Journal of Consumer Research, 22(3), 305-313. Doi: http://dx.doi.org/10.1086/209452.

[30] SHARMA, P., SIVAKUMARAN, B., \& MARSHALL, R. (2010). Impulse Buying And Variety Seeking: A Trait-Correlates Perspective. Journal of Business Research, 63(3), 276-283. doi: 10.1016/j.jbusres. Doi: doi:10.1016/j.jbusres.2009.03.013.

[31] SILVERA, D. H., LAVACK, A. M. \& KROPP, F. (2008). Impulse Buying: The Role Of Affect, Social Influence, And Subjective Wellbeing. Journal of Consumer Marketing, 25(1), 23-33. Doi: http://dx.doi.org/10.1108/07363760810845381.
[32] SPROLES, G.B. \& KENDALL, E.L. (1986). A Methodology For Profiling Consumer Decision-Making Styles. The Journal of Consumer Affairs, 20, Winter, 267-279. Doi: 10.1111/j.1745-6606.1986.tb00382.x.

[33] STERN, H. (1962). The Significance Of İmpulse Buying Today. Journal of Marketing, 26, April, 59-63. Doi: $10.2307 / 1248439$.

[34] TORUN, A. (2006). Stres ve Tükenmişlik, Endüstri ve Örgüt PsikolojisiTürk. Psikologlar Derneği ve Kal-Der, 45-47.

[35] VERPLANKEN, B., \& HERABADI, A. (2001). Individual Differences In Impulse Buying Tendency: Feeling And No Thinking. European Journal of Personality, 15, S71-S83. doi: 10.1002/per.423. Doi: 10.1002/per.423.

[36] VERPLANKEN, B., HERABADI, A. G., PERRY, J. A., \& SILVERA, D. H. (2005). Consumer Style And Health: The Role Of Impulsive Buying In Unhealthy Eating. Psychology \& Health, 20(4), 429-441 http://dx.doi.org/10.1080/08870440412331337084.

[37] WEINBERG, P. \& GOTTWALD, W. (1982). Impulsive Consumer Buying As A Result Of Emotions. Journal of Business Research, 10, 43-57. Doi: 10.1016/0148-2963(82)90016-9.

[38] WOOD, M. (1998). Socio Economic Status, delay of gratification, and Impulsive Buying. Journal of Economic Psychology, 19, 295-320.

[39] YOUN, S., \& FABER, R. J. (2000). Impulse buying: its relation to personality traits and cues. Advances in consumer research, 27, 179-185. 